\title{
Non-Keratinizing Malignant Squamous
} Cell

National Cancer Institute

\section{Source}

National Cancer Institute. Non-Keratinizing Malignant Squamous Cell. NCI Thesaurus.

Code C36792.

A malignant squamous cell that does not produce keratin. 